\title{
Manajemen Penyelenggaraan Program Pelatihan Masyarakat (Studi di Balai Besar Pemberdayaan Masyarakat dan Desa Kementerian Dalam Negeri di Malang)
}

\author{
Christova Hesti Wardhani ${ }^{1 *}$, Sumartono, Prof,Dr, $\mathrm{MS}^{2}, \mathrm{M}$. Makmur, Dr,MS ${ }^{3}$
}

1Jurusan Ilmu Administrasi Publik, Fakultas Ilmu Administrasi, Universitas Brawijaya

\begin{abstract}
Abstrak
Tujuan negara adalah mensejahterakan rakyatnya melalui pelayanan publik. Kapasitas sumber daya manusia yang rendah menjadi penghambat dalam pelayanan publik. Pengembangan kapasitas dapat dilakukan melalui pelatihan sebagai investasi yang harus ada dalam organisasi. Pengembangan sumberdaya manusia yang dikelola dengan baik penting sebagai sarana mencapai tujuan pembangunan secara efektif. Balai Besar Pemberdayaan Masyarakat dan Desa di Malang adalah instansi penyelenggara pelayanan publik bidang pelatihan bagi pelayan publik di desa. Penelitian ini memberikan gambaran mengenai manajemen penyelenggaraan program pelatihan masyarakat dengan pendekatan kualitatif dan analisis Straus dan Corbin. Hasil penelitian menunjukkan bahwa unsur manajemen telah dilaksanakan dalam penyelenggaraan program pelatihan. Terdapat unsur planing dan organizing dalam tahapan perencanaan, unsur actuating dalam tahapan pelaksanaan pelatihan unsur controlling dalam tahapan penilaian, serta adanya review dan perbaikan pelatihan. Pelayanan publik melalui penyelenggaraan program pelatihan masyarakat bertujuan meningkatkan kapasitas sumber daya manusia utamanya penyelenggara pemerintahan didesa menjadi layanan yang diselenggarakan negara karena jenis layanan tersebut tidak dapat diselenggarakan oleh korporasi maupun pasar dikarenakan manfaat program yang tidak berhubungan langsung dengan kepentingan pasar untuk meraih profit. Program pelatihan masyarakat memberikan penguatan kapasitas masyarakat dalam penyelenggaraan pemerintahan desa berdasarkan peraturan perundangan yang berlaku. Program pelatihan dilaksanakan oleh pemerintah untuk mencapai tujuan dan misi negara mengacu pada peraturan yang berlaku.
\end{abstract}

Kata kunci: Manajemen, Pelatihan Masyarakat, Pelayanan Publik

\section{Abstract}

The aim is to improve the welfare of its people through the state public service. Human resource capacity of the low is the bottleneck in the public service. Capacity development can be done through training as an investment that must exist in the organization. Development of human resources is well managed is important as a means of achieving development goals effectively. Great Hall of the Community Development in Malang are providers of public services agency field training for public servants in the village. This study gives an overview of the management of community training programs with a qualitative approach and analysis Straus and Corbin. The results showed that the management elements have been implemented in the administration of training programs. There are elements of planing and organizing the planning stages, actuating element in the training phase of the controlling element in the appraisal, as well as the review and improvement of training. Public services through the implementation of community training programs aimed at increasing the capacity of human resources became the main organizer of the village administration services administered by the state for these types of services can not be held by the corporation and the market because of the benefits of a program that is not directly related to the interests of the market to achieve a profit. Community training program provides community capacity building in governance village by applicable legislation. The training program implemented by the government to achieve the goals and mission of the country refers to the regulations.

Keywords: Management, Community Training, Public Services

\section{PENDAHULUAN}

Keinginan mendasar dalam pembentukan sebuah negara adalah untuk mensejahterakan rakyatnya dalam berbagai sisi kehidupan,

Alamat Korespondensi Penulis: Christova Hesti Wardhani

Email : christi_hesti@yahoo.co.id

Alamat : Jl. Mayjen Haryono No. 163 Malang 65145 pendidikan dan lebih luas lagi agar memberikan dampak positif bagi dunia sekitar. Cita-cita tersebut diamanatkan kepada pemerintah untuk dilaksanakan melalui pembangunan dan pelayanan kepada masyarakat yang menegaskan fungsi birokrasi sebagai pelayan publlik. Pelayan publik yang handal haruslah memiliki kemampuan yang mencukupi untuk mendukung terselenggaranya pelayanan publik. Sebagai 
ujung tombak pelayanan publik di tingkat terendah, desa menuntut sebuah perhatian khusus dalam peningkatan kapasitas sumber daya manusia. Peningkatan kapasitas sumber daya manusia secara menyeluruh adalah amanat yang disampaikan dalam Peraturan Pemerintah Nomor 72 Tahun 2005 tentang Desa pada pasal 98 bahwa pemerintah dan pemerintah provinsi wajib membina penyelenggaraan pemerintahan desa dan lembaga kemasyarakatan. Hal tersebut direspon dengan lahirnya Peraturan Menteri Dalam Negeri No 19 Tahun 2007 tentang Pelatihan Masyarakat, dimana Kepala Desa, Perangkat Desa, anggota Badan Permusyawaratan Desa, Lurah, Perangkat Kelurahan, Pengurus Lembaga Kemasyarakat, Pengurus Kelompok-Kelompok Masyarakat, Kader Pemberdayaan Masyarakat, Tokoh Masyarakat, Warga Masyarakat adalah kelompok sasaran dalam program pelatihan masyarakat. Tujuan pelatihan masyarakat adalah penguatan pemerintahan desa dan kelurahan, lembaga kemasyarakatan dan upaya dalam penguatan kapasitas masyarakat. Peran pembinaan dan pengawasan penyelenggaraan pemerintahan desa oleh pemerintah tersebut dipertegas lagi dalam Undang-Undang Nomor 6 Tahun 2014 tentang Desa pasal 112, bahwa pemerintah dalam hal ini adalah Menteri Dalam Negeri yang melakukan pembinaan umum penyelenggaraan pemerintahan desa dan pemberdayaan masyarakat. Pemberdayaan masyarakat dalam hal ini dilaksanakan dalam bentuk pendampingan termasuk penyediaan sumber daya manusia pendamping dan manajemen.

Pengembangan sumber daya manusia merupakan suatu bentuk investasi (human investment) dan suatu conditio sine quanon (harus ada dan terjadi dalam suatu organisasi), namun dalam pelaksanaannya perlu mempertimbangkan faktor-faktor yang berpengaruh baik dari dalam maupun luar sebuah organisasi [1].

Keusangan pengetahuan, keahlian dan keterbatasan informasi pada diri karyawan pada akhirnya menurunkan kemampuannya menjalankan tugas-tugasnya. Begitu pula dengan tantangan-tantangan baru yang dihadapi organisasi menyebabkan karyawan seringkali kehilangan kompetensi dan wawasan yang cukup untuk menjawab tantangan tersebut [2]. Membangun kemampuan bersaing melalui peningkatan kualitas sumberdaya manusia berarti fungsi pengembangan dalam bentuk kegiatan antara lain pelatihan atau pendidikan kembali, perencanaan dan pengembangan karir karyawan yang berorientasi pada tujuan, merupakan langkah konstruktif peningkatan sumberdaya manusia termasuk peningkatan motivasi kerja dalam rangka membangun keunggulan kompetitif, mengelola sumber daya manusia organisasi adalah adalah investasi (human investment) bagi organisasi. Manusia bukanlah alat produksi tetapi partner dalam mencapai tujuan organisasi [2].

Secara konvensional, pengembangan sumber daya manusia diartikan sebagai investasi human capital yang harus dijalankan sejalan dengan investasi physical capital [3]. Pendidikan dan pelatihan merupakan bagian yang tak terpisahkan dari suatu sistem pengembangan sumber daya manusia, dengan pendidikan dan pelatihan dapat diharapkan bahwa pegawai/karyawan dapat meningkatkan dirinya baik pengetahuan maupun ketrampilannya sehingga sikapnya menjadi matang untuk menghadapi perubahan yang terjadi di lingkungan organisasi [4].

Pendidikan dan pelatihan bagi masyarakat adalah salah satu bentuk pelayanan umum yang diselenggarakan oleh negara. "Pelayanan umum adalah suatu usaha yang dilakukan kelompok atau seseorang atau birokrasi untuk memberikan bantuan kepada masyarakat dalam rangka mencapai suatu tujuan tertentu" [4].

Pengelolaan program pelatihan tidak berbeda dengan pengelolaan program yang lainnya. Namun, pengelolaan program pelatihan diremehkan dan tidak ditangani secara serius sebagaimana program pembangunan fisik. Hal ini karena rendahnya kesadaran dan pengertian pihak penyelenggara dan pihak lain yang terkait. Sebagai suatu proses, istilah manajemen adalah berkenaan dengan orang yang bertanggung jawab menjalankan organisasi dan proses menjalankan organisasi itu sendiri yaitu dengan pemanfaatan sumber daya seperti orang dan mesin untuk mencapai tujuan organisasi menurut Shafritz dan Russel (1997) dalam [5].

Persoalan mendasar pada program pelatihan masyarakat antara lain adalah tidak seimbangnya antara jumlah peserta yang dilatih jika dibandingkan dengan keseluruhan target sasaran, kenaikan anggaran dari tahun ke tahun namun belum sebanding dengan kebutuhan pelatihan sesuai dengan jumlah desa yang ada, kendala komunikasi ketika menghubungi kabupaten peserta pelatihan, keragaman asal daerah peserta pelatihan menyebabkan banyak kendala dalam penyelenggaraan pelatihan, mulai 
dari menu makanan hingga metode penyampaian oleh fasilitator dan program monitoring dan evaluasi pasca pelaksanaan pelatihan terkendala karena posisi daerah yang sulit untuk dijangkau.

Berdasarkan hal tersebut maka dalam penelitian ini dilakukan perumusan masalah yaitu bagaimanakah manajemen penyelenggaraan program pelatihan masyarakat di Balai Besar Pemberdayaan Masyarakat dan Desa Kementerian Dalam Negeri di Malang ?. Tujuan penelitian ini untuk memberikan gambaran tentang manajemen penyelenggaraan program pelatihan masyarakat di Balai Besar Pemberdayaan Masyarakat dan Desa Kementerian Dalam Negeri di Malang dengan mempertimbangkan kebutuhan pelatihan dan disesuaikan dengan kapasitas sarana prasarana, pelatih dan anggaran yang ada.

\section{METODE PENELITIAN}

Penelitian ini merupakan penelitian deskriptif dengan menggunakan pendekatan kualitatif. Dengan pendekatan ini peneliti dapat memperoleh gambaran yang lengkap dari permasalahan yang dirumuskan dengan memfokuskan pada proses dan pencarian yang dikaji lebih bersifat komprehensif, mendalam, alamiah dan apa adanya.

\section{Metode Pengumpulan Data}

Penelitian ini menggunakan metode pengamatan, wawancara dan dokumentasi. Metode pengamatan (Observation) dilakukan dengan melihat secara langsung proses penyelenggaraan program pelatihan masyarakat. Metode wawancara dilakukan dengan melakukan tanya jawab dengan pejabat dan juga staff. Metode dokumentasi digunakan dengan melihat dokumen Rencana Kerja, LAKIP, Pedoman Penyelenggaraan Pelatihan dan Laporan Penyelenggaraan Pelatihan di Balai Besar Pemberdayaan Masyarakat Tahun 2013.

\section{HASIL DAN PEMBAHASAN}

Pelayanan Publik Dalam Penyelenggaraan Program Pelatihan Masyarakat

Pelayanan publik tidak lagi dapat ditentukan dengan melihat lembaga penyelenggaraan, pemerintah atau swasta [6]. Pelayanan publik harus dilihat dari karakteristik dan sifat dari pelayanan itu sendiri, bukan dari karakteristik lembaga penyelenggaraan atau sumber pembiayaannya. Kriteria yang digunakan sebagai berikut :
1) Sifat dari barang dan jasa yang tidak dapat diselenggarakan oleh korporasi atau pasar

2) Tujuan dari penyediaan barang dan jasa. Penyediaan barang dan jasa yang dilakukan untuk mencapai tujuan dan misi negara yang diatur dalam konstitusi atau peraturan perundangan lainnya.

Pelayanan publik melalui penyelenggaraan program pelatihan masyarakat bertujuan meningkatkan kapasitas sumber daya manusia utamanya penyelenggara pemerintahan didesa yaitu kepala desa dan perangkatnya, badan permusyawaratan desa, lembaga kemasyarakatan dan warga masyarakat lainnya. Hal ini menjadi layanan yang diselenggarakan negara karena jenis layanan tersebut tidak dapat diselenggarakan oleh korporasi maupun pasar dikarenakan manfaat program yang tidak berhubungan langsung dengan kepentingan pasar untuk meraih profit. Program pelatihan masyarakat memberikan penguatan kapasitas masyarakat dalam penyelenggaraan pemerintahan desa berdasarkan peraturan perundangan yang berlaku. Program pelatihan dilaksanakan oleh pemerintah untuk mencapai tujuan dan misi negara dalam penyelenggaraan pemerintahan desa, agar pelayanan masyarakat di desa dapat dilaksanakan mengacu pada peraturan yang berlaku.

Orientasi pada pelayanan menunjuk pada seberapa banyak energi birokrasi dimanfaatkan untuk penyelenggaraan pelayanan publik. Sistem pemberian pelayanan yang baik dapat dilihat dari besarnya sumber daya manusia yang dimiliki oleh birokrasi secara efektif didayagunakan untuk melayani kebutuhan dan kepentingan pengguna jasa. Contohnya adalah masalah penyediaan waktu kerja aparat yang berorientasi pada pemberian pelayanan kepada masyarakat [7]. Secara umum seluruh pejabat dan staff telah melakukan penggunaan waktu kerjanya untuk keperluan pelayanan publik kepada peserta pelatihan, hal tersebut diatur dalam peraturan jam kerja dan jadwal pelatihan. Berdasarkan hasil pengamatan dilihat bahwa saat pelatihan berlangsung petugas melaksanakan tugas sesuai dengan jadwal, jarang sekali ditemukan petugas yang mangkir dari tanggung jawab bahkan ketika terjadi penugasan di luar jam kerja yaitu sebelum pukul 8 pagi atau diatas pukul 4 sore.

Program pelatihan masyarakat yang dilaksanakan oleh Balai Besar Pemberdayaan Masyarakat dan Desa Kementerian Dalam Negeri di Malang adalah salah satu bentuk pelayan publik di bidang kemasyarakatan khususnya 
bidang pendidikan dalam hal ini pendidikan non formal (pendidikan luar sekolah) untuk orang dewasa dalam bentuk pelatihan. Pelayanan di bidang kemasyarakatan tampak jelas dari sasaran pelatihan adalah anggota masyarakat yang memiliki tugas dan tanggung jawab dalam bidang pemerintahan desa maupun lembaga kemasyarakatan seperti PKK, LPMD, RT, RW, serta kelembagaan ekonomi masyarakat.

Penyelenggaraan pelayanan publik sesuai dengan bentuk dan sifatnya, dapat menggunakan salah satu dari pola-pola berikut yaitu pola pelayanan fungsional, yaitu pola pelayanan publik yang diberikan oleh suatu instansi pemerintah sesuai dengan tugas, fungsi dan kewenangnya berdasarkan Keputusan No. 63/ KEP/ M.PAN/ 7/ 2003 mengenai pola penyelenggaraan pelayanan publik. Balai Besar Pemberdayaan Masyarakat dan Desa Kementerian Dalam Negeri di Malang melaksanakan tugas pokok dan fungsinya dalam bidang pelatihan masyarakat sesuai dengan Peraturan Menteri Dalam Negeri Nomor 21 Tahun 2006.

Kajian dan praktek birokrasi pelayanan publik di berbagi negara senantiasa terus berkembang mengikuti perkembangan zaman. Perubahan terjadi dikarenakan semakin meningkatnya tingkat kepuasan masyarakat serta kondisi global yang menghendaki para pelayan publik dinamis untuk memenuhinya. Tiga perspektif dalam administrasi publik adalah Old Public Administratration, New Public Manajement dan New Public Service.

Pendekatan The Old Public Administration atau yang kerap disebut sebagai paradigma administrasi tradisional ini tidak cukup representatif untuk mewakili kepentingan masyarakat. Masyarakat tidak diberikan banyak ruang untuk ikut terlibat dalam proses penyelenggaraan pelayanan publik. Dominasi negara masih cukup kuat, sementara keterlibatan partisipasi dan aspirasi masyarakat dalam teori cenderung ditolak/dipersempit sehinga keadilan sosial terabaikan dan dianggap tidak mampu memecahkan masalah yang dihadapi masyarakat, hal ini jauh dari nilai dan cita-cita demokrasi yang menempatkan posisi masyarakat sangat istimewa [8].

Konsep utama yang ditawarkan dalam pendekatan New Public Management adalah menempatkan posisi masyarakat sebagai customer (pelanggan), pemerintah sebagai agen pemberi layanan publik menjadikan masyarakat sebagai pihak yang dilayani dalam posisi pelanggan, dimana hubungan kedua pihak ini terbentuk pola hubungan yang dilakukan dalam dunia pasar (market place). New Public Management berkehendak meningkatkan efisiensi, efektivitas dan produktivitas sehingga kurang memperhatikan keadilan sosial. Pengelolaan pelayanan publik yang diserahkan kepada pihak swasta pada satu sisi memang meningkatkan kinerja pelayanan publik, namun cenderung hanya dinikmati oleh orang yang mampu membayar [8].

Paradigma The New Public Services menempatkan masyarakat sebagai pemilik kedaulatan. Uraian tersebut jelas menunjukkan bahwa masyarakat memiliki hak untuk dilayani dan pemerintah wajib memberikan pelayanan sebaik-baiknya. Administratur publik bertanggung jawab dalam terselenggaranya pelayanan publik dengan cara memberikan pelayanan yang terbaik kepada masyarakat untuk meningkatkan kesejahteraan [9]. Sebagai pemberi dana dalam wujud pembayaran pajak, retribusi dan berbagai pungutan lainnya maka sudah seharusnya warganegara mendapatkan pelayanan terbaik dari pemerintah sebagai pemenuhan hak warganegara.

Dalam paradigma New Public Service terdapat unsur-unsur yang terdapat dalam program pelatihan masyarakat di Balai Besar Pemberdayaan Masyarakat dan Desa Kementerian Dalam Negeri di Malang. Salah satu unsur tersebut adalah program pelatihan masyarakat ini tidak berfokus pada usaha mendapatkan uang dari masyarakat namun lebih berprinsip pada pelayanan kepada masyarakat untuk meningkatkan kapasitas sehingga mereka dapat berpartisipasi dan terlibat langsung dalam jalannya pemerintahan sesuai dengan tugasnya.

Hal ini terlihat dari program pelatihan yang menjadikan masyarakat sebagai sasarannya. Masyarakat diberikan pelayanan yang layak dalam proses pelatihan, mulai dari asrama, makanan yang bergizi, cara mengajar partisipatif, fasilitas kesehatan,fasilitas olah raga hingga kebutuhan mereka secara personal untuk mendapatkan menu sesuai dengan kondisi mereka. Pelayanan tersebut bukan hanya ketika mereka mendapatkannya sesuai standard namun mereka juga mendapatkan kesempatan untuk mempengaruhi layanan, salah satunya dengan membuka peluang untuk memberikan saran dan komentar selama jalannya pelatihan. Proses pelibatan warga negara dalam program pelatihan di instansi ini telah dimulai dari ujung program yaitu tahap perencanaaan, kemudian berlanjut 
pada pelibatan peserta pada saat pelaksanaan pelatihan hingga proses monitoring dan evaluasi pasca pelatihan. Proses ini bukanlah tanpa kendala karena harus dilakukan pelibatan pada pemerintah daerah untuk menyadari bahwa pelatihan secara berkelanjutan adalah kepentingan bersama. Komitmen pemerintah daerah diambil pada saat identifikasi kebutuhan pelatihan dan temu karya selama proses perencanaan. Seringkali pemerintah daerah merasa bahwa program pelatihan bukanlah kepentingannya sehingga tidak perlu untuk ditindaklanjuti dan apabila ditindaklanjuti haruslah dengan dana pemerintah pusat. Penyadaran terhadap pemerintah daerah harus dilakukan secara terus menerus agar pemikiran untuk menjadikan pelatihan sebagai sebuah kebutuhan akhirnya terwujud menjadi sebuah program tindak lanjut yang berkesinambungan.

\section{Manajemen penyelenggaraan program pelatihan masyarakat}

Pelatihan sebagai suatu cara yang digunakan untuk memberikan atau meningkatkan ketrampilan yang dibutuhkan untuk melaksanakan pekerjaan sekarang [10]. Program pelatihan masyarakat ditujukan bagi peserta yang berasal dari unsur Kepala Desa, Sekretaris Desa, ketua Lembaga Pemberdayaan Masyarakat (LPMD/LPMK), ketua Badan Permusyawaratan Desa (BPD), Tim Penggerak PKK Desa, pengurus Badan Usaha Milik Desa pelaku usaha ekonomi masyarakat, dan peserta lainnya sesuai dengan jenis pelatihan. Program pelatihan memberikan peningkatan kapasitas peserta pelatihan dalam pengetahuan (knowledge), ketrampilan (skill), dan sikap (attitude) secara menyeluruh, walaupun memang ditekankan pada peningkatan ketrampilan, sedangkan peningkatan pengetahuan diperlukan untuk menunjang pengertian peserta mengenai hal-hal yang mendasari ketrampilan. Nilai sikap dirangsang dengan mengajak mereka pada lokasi studi lapang, namun nilai sikap ini memerlukan waktu karena peserta memerlukan adaptasi dan internalisasi terhadap materi pelatihan.

Balai Besar Pemberdayaan Masyarakat dan Desa Kementerian Dalam Negeri di Malang melaksanakan program pelatihan dengan melaksanakan tahapan perencanaan pelatihan, pelaksanaan pelatihan, penilaian pelatihan, review pelatihan, serta perbaikan pelatihan, tahapan tersebut setidaknya telah memenuhi tahapan manajemen yaitu : planing, organisingcoordinating, commanding, controling.Tiap tahapan dilakukan kegiatan untuk menunjang tahapan tersebut.

\section{Perencanaan Pelatihan}

Perencanaan pelatihan di Balai Besar Pemberdayaan Masyarakat dan Desa Kementerian Dalam Negeri di Malang meliputi proses identifikasi kebutuhan pelatihan, penyusunan rencana kerja dan temu karya. Barnadin dan Russel (1996) dalam [11] menjelaskan mengenai analisis kebutuhan pelatihan berikut ini : Penilaian/ analisis kebutuhan pelatihan (need assesment), yang bertujuan mengumpulkan informasi untuk menentukan dibutuhkan atau tidaknya program pelatihan. Identifikasi kebutuhan pelatihan bertujuan untuk mengetahui kebutuhan peserta mengenai jenis pelatihan yang diharapkan dapat meningkatkan kapasitasnya dalam melaksanakan tugas sehari-hari, untuk itulah dilakukan kunjungan ke daerah-daerah untuk mendapatkan gambaran secara langsung mengenai jenis pelatihan yang dibutuhkan.

Proses analisis kebutuhan pelatihan, sasaran analisis ditujukan untuk mendapatkan data-data yang diperlukan untuk rancangan (design) pelatihan [12]. Adapun data atau informasi yang dikumpulkan dan dianalisis pada analisis kebutuhan pelatihan adalah : 1) Optimal, data ketrampilan atau pengetahuan yang seharusnya dimiliki, 2) Actual, ketrampilan dan pengetahuan yang dimiliki saat ini, 3) Feeling, pendapatpendapat yang disampaikan oleh tenaga pengajar, penyedia/ supervisor atau orang lain terkait dengan masalah pendidikan dan pelatihan, 4) Causes, alasan-alasan mengapa ada masalah pendidikan, apa sebabnya diperlukan pelatihan atau unsur-unsur pelatihannya

Data yang diperoleh dalam pelaksanaan identifikasi kebutuhan pelatihan berupa angka meliputi jumlah desa, jumlah pelatihan yang telah dilaksanakan, jumlah perangkat desa maupun data berdasarkan hasil wawancara. Data tersebut lebih bersifat data actual. Sedangkan data optimal kita ketahui lewat peraturan yang membentuk sebuah lembaga tersebut. Misalkan untuk pelatihan Manajemen Badan Usaha Milik Desa, data optimal kita peroleh lewat Peraturan Menteri Dalam Negeri Nomor 39 Tahun 2010. Data yang berasal dari causes dan feeling belum banyak menjadi pertimbangan dalam perencanaan lewat identifikasi kebutuhan pelatihan. Hal ini mengingat bahwa pelaksana identifikasi kebutuhan pelatihan adalah pejabat dan staf (jabatan fungsional umum), jika terdapat jabatan fungsional khusus pelatih masyarakat, 
data causes dan feeling dapat diwujudkan untuk melengkapi data.

Teknik dan analisis pengumpulan data digunakan suatu metode/alat sesuai dengan teknik yang digunakan, adalah interview, observasi, group pengamat, kuisioner [12]. Teknik yang dilakukan instansi dalam melakukan identifikasi kebutuhan pelatihan meliputi interview dengan pejabat maupun staf Badan Pemberdayaan Masyarakat provinsi dan kabupaten mengenai jenis dan kebutuhan masyarakat terhadap pelatihan. Identifikasi kebutuhan pelatihan dilaksanakan oleh tim Balai Besar Pemberdayaan Masyarakat dan Desa Kementerian Dalam Negeri di Malang yang berjumlah antara 2 hingga 3 orang, kerja tim bertujuan untuk mempertajam informasi yang didapat. Wawancara dilakukan juga kepada sasaran pelatihan. Proses interview diarahkan dengan daftar pertanyaan yang dipersiapkan oleh seksi penyusunan program. Daftar pertanyaan berusaha untuk menggali kebutuhan pelatihan sebuah kabupaten. Observasi dilakukan dengan mendatangi kabupaten sasaran pelatihan dan melihat dukungan sarana prasarana, lingkungan serta budaya. Kuisioner merupakan metode yang jarang digunakan dalam identifikasi kebutuhan pelatihan dan lebih banyak menggunakan teknik wawancara.

Kegiatan Temu Karya adalah kegiatan dilakukan dalam upaya menjalankan fungsi manajemen yaitu dalam bidang mengorganisasi dan mengkoordinasi seperti yang disampaikan oleh Gullick dan Urwick yang dikutip dalam [13] bahwa Organizing, suatu proses pembagian kerja yang disertai dengan pendelegasian wewenang. Temu karya adalah proses koordinasi antara penyelenggara dengan kabupaten calon peserta pelatihan. Koordinasi merupakan fase dimana seluruh pihak yang terkait dalam program pelatihan menyepakati hak dan kewajibannya serta berkomitmen untuk melaksanakannya. Pengorganisasian bertujuan melakukan pembagian tugas antara penyelenggara dan kabupaten calon peserta. Penyelenggara berperan dalam pelaksanaan program pelatihan, sedangkan kabupaten berperan dalam hal pemilihan peserta serta pembinaan pasca pelatihan.

Perencanaan pelatihan lebih memfokuskan pada perencanaan jenis pelatihan jumlah dan kabupaten asal peserta namun tidak merencanakan secara menyeluruh khususnya tentang metode pelatihan. Hal ini seperti disampaikan oleh Bapak Drs. Jarot Sunjoto, MM
Bagian Pemberdayaan Aparatur Desa dan Kelurahan sebagai berikut :
Seharusnya memang direncanakan pengembangan metode dan sistemnya mbak, tapi disini belum itu, masih sambil lalu ndak terlalu serius. Nanti itu ikutnya waktu penyusunan modul. Tapi waktu perencanaan itu ya ndak ada memikirkan metodenya atau dikembangkan gimana gitu ya wis yang penting jenisnya apa, berapa orangnya dari mana asalnya (Wawancara 6 Juni 2014).

Secara umum dapat kita lihat bahwa perencanaan pelatihan yang dilakukan lebih bersifat pada teknis pelatihan, atau hal-hal yang berkaitan dengan pekerjaan kepanitiaan dalam menjalankan sebuah program. Perencanaan mendalam dan terperinci mengenai esensi pelatihan belum dilakukan secara khusus, antara lain mengenai metode penyampaian, substansi materi, pengembangan dan pembedahan materi. Pelaksanaan Pelatihan

Dalam penelitian berjudul Training Strategically Improves Human Resource (HR) Productivity in Academic Institutions of Pakistan menjelaskan bahwa pelatihan akademis berguna agar peserta mendapatkan keterampilan profesional dan menanamkan kemampuan intelektual [14]. Pelatihan adalah proses belajar tetapi ada kebutuhan menyebarkan pengetahuan, sehingga peserta pelatihan dapat menjadi pelatih juga bagi sekitarnya. Hal yang perlu diperhatikan pada program pelatihan adalah tindakan korektif untuk peserta guna meningkatkan produktivitas, keterampilan dan pengembangan program pelatihan. Usia peserta 25-40 menunjukkan minat dalam mengelola dan menyebarkan pengetahuan. Pelatihan dan pengetahuan adalah sebagai alat untuk melakukan perubahan budaya lembaga dan meningkatkan efisiensi karyawan. Pelatihan di Balai Besar Pemberdayaan Masyarkat dan Desa di Malang belum menetapkan batasan usia peserta pelatihan, sehingga seringkali pelatihan diikuti oleh peserta dengan usia diatas 60 tahun yang kurang menunjukkan minat untuk melakukan perubahan lembaga ke arah lebih baik apalagi menyebarkan materi pelatihan.

Pelaksanaan pelatihan di Balai Besar Pemberdayaan Masyarakat dan Desa Kementerian Dalam Negeri di Malang dilaksanakan di ruang kelas yang dilengkapi dengan asrama serta berlokasi diluar area kerja peserta pelatihan selama 7 hari atau 5 hari efektif. Metode pelatihan tersebut adalah off the 
job training yaitu pelatihan yang dilaksanakan diluar tempat dan diluar waktu kerja [15]. Pelaksanaan pelatihan di instansi ini menggunakan kedua metode dalam off the job training baik simulasi maupun presentasi. Teknik simulasi yang kerap digunakan adalah studi kasus, role playing (bermain peran). Teknik presentasi informasi yang kerap digunakan meliputi: Lecture (kuliah), Conference (konferensi), Video presentation, Program instruction. Dari berbagai metode yang telah digunakan, metode video presentation belum dipersiapkan secara khusus, hanya sekedar variasi di tengah kejenuhan peserta. Hal ini disebabkan belum adanya tim khusus multimedia yang berkonsentrasi penuh pada penggunaan multimedia dalam menyampaikan materi. Perlu dikembangkan metode lainnya yaitu self study, supervising (reading and research - tugas baca dan riset yang diawasi), serta outbond/widerness (pelatihan alam terbuka).

Pelaksanaan program pelatihan bukan hanya dengan menggunakan metode di dalam kelas, namun juga di luar kelas yang disebut studi lapang. Kunjungan lapang merupakan media yang penting dalam pembelajaran orang dewasa yang bertujuan untuk mengamati situsasi, kegiatan, praktik atau menemui obyek tertentu yang tidak dapat dibawa ke kelas dan biasanya berjangka waktu pendek atau tidak lebih dari tiga jam [16]. Studi lapang untuk melihat secara langsung penerapan dari teori yang telah didapat di dalam kelas dan biasanya dilakukan kunjungan ke kantor desa, dan tempat usaha.

Mengingat pentingnya proses pembelajaran, maka pelatih masyarakat harus menjalankan tugasnya dengan baik, mulai dari input pelaksanaan pelatihan (antara lain: pelatih, peserta, biaya, sarana dan prasarana), sampai pelaksanaan pembelajaran itu sendiri, sehingga dapat dihasilkan output yang sesuai dengan apa yang ingin dicapai dalam tujuan pelatihan. Hal tersebut mengisyaratkan bahwa tenaga kediklatan memiliki tugas dan peran yang penting dalam proses pembelajaran, guna terbentuknya kompetensi peserta diklat. Tenaga kediklatan mulai dari penyelenggara hingga pelatih dituntut untuk menjalankan tugasnya secara profesional. Profesionalisme dari sebuah lembaga ditentukan oleh profesionalisme penyelenggara, karena penyelenggara dianggap memiliki akses dan kontrol terhadap sumber-sumber yang diperlukan untuk memperlancar penyelenggaraan. $\begin{array}{cccc}\text { Pelatih masyarakat } & \text { Balai } & \text { Besar } \\ \text { Pemberdayaan } & \text { Masyarakat dan } & \text { Desa }\end{array}$ Kementerian Dalam Negeri di Malang berasal dari lingkungan Balai sehingga memiliki pengalaman mengajar 3 tahun hingga puluhan tahun. Hal ini menyebabkan mereka mengerti karakteristik peserta maupun berbagai materi pelatihan. Pelatih masyarakat dibekali dengan pengetahuan metodologi pembelajaran orang dewasa sehingga memudahkan mereka untuk dapat menyampaikan materi sesuai dengan karakteristik orang dewasa. Pannen (1997) dalam [16] menyebutkan bahwa belajar bagi orang dewasa berhubungan dengan bagaimana mengarahkan diri sendiri untuk bertanya dan mencari jawabannya. Dari situlah pelatih masyarakat berusaha untuk menarik minat peserta pelatihan melalui metode belajar partisipatif dimana peserta terlibat secara langsung dalam proses pelatihan.

Kendala dalam pelaksanaan pelatihan adalah tidak tersedianya jabatan fungsional pelatih masyarakat, seperti ditegaskan oleh Ibu Iswahyuningsih SH, MM, Kepala Sub Bagian Persuratan dan Kepegawaian sebagai berikut :

Disini tidak ada jabatan fungsional teknis pelatih masyarakat, seharusnya 3 atau 4 orang per seksi pelatihan. Jadinya banyak yang tugas ganda, seperti saya juga tugas ganda jadi kasie juga jadi pelatih masyarakat. Kalo misalnya ada pelatih masyarakat khusus kan team teachingnya bisa jalan maksimal,di kelas ada yang stand by. Kalau sekarang mau stand by masih kepikiran administrasi, laporan, surat, pasti langsung kembali ke ruangan kalau habis ngajar, ndak bisa nunggoni.Sudah saya ajukan ke biro kepegawaian, tapi 2 tahun ini kan moratorium jadi kita ndak dapat pegawai baru (Wawancara tanggal 14 Mei 2014).

\section{Penilaian Pelatihan}

Balai Besar Pemberdayaan Masyarakat dan Desa Kementerian Dalam Negeri di Malang melaksanakan evaluasi selama berlangsungnya pelatihan yang disebut penilaian pelatihan. Pengukuran efektivitas pelatihan meliputi : 1) Reaksi, bagaimana respon peserta, 2) Pembelajaran, pengetahuan, keahlian dan sikap melalui pretest maupun post test, 3) Perilaku, perubahan yang terjadi sebagai akibat pelatihan, 4) Hasil, dampak pelatihan pada efektivitas organisasi [17]. Penilaian reaksi dan pembelajaran dapat kita lakukan selama berlangsungnya pelatihan sedangkan perilaku dan hasil dapat kita lihat seusai pelatihan 
berlangsung. Hal tersebut sebagaimana disampaikan oleh Ibu Endang Hernanik, SH, MAP, Kepala Seksi Pemberdayaan Aparatur Desa sebagai berikut :

Berdasarkan hasil evaluasi harian kita lakukan penyelesaian, untuk yang berhubungan dengan pelaksanaan pelatihan di kelas saya tangani, sedangkan untuk sarana dan prasarana saya sampaikan ke bagian umum. Biasanya yang ke bagian umum berkaitan dengan lampu mati, atau handel pintu, atau kebutuhan asrama lainnya. Kalau untuk yang di kelas bisa saya tangani tentu saja koordinasi dengan panitia lainnya (Wawancara 21 Mei 2014).

Penilaian reaksi dilakukan saat pelatihan berlangsung, baik usai penyampaian materi di kelas maupun usai pelaksanaan studi lapang mengenai respon peserta apakah peserta mendapatkan manfaat dari pelatihan tersebut. Untuk menunjukan tingkat pemahaman peserta sebelum dan sesudah pelaksanaan pelatihan utamanya dalam hal pengetahuan dilaksanakan pre test dan post test.

\section{Review Pelatihan}

Penyelenggara melaksanakan review pasca pelaksanaan program pelatihan dengan melaksanakan monitoring dan evaluasi. Monitoring dan evaluasi pasca pelatihan dilaksanakan dalam rentang waktu satu hingga 3 tahun setelah program pelatihan masyarakat dilaksanakan. Inumerator melaksanakan kegiatan ini berbekalkan kuisioner ataupun daftar pertanyaan, daftar pertanyaan tersebut bertujuan untuk mengorek informasi yang mendalam dari peserta mengenai tanggapan mereka terhadap pelatihan yang telah mereka ikuti, apakah pelatihan memberikan manfaat untuk pelaksanaan tugas sehari-hari. sebagaimana dijelaskan oleh Bapak Drs. Khumaidi, MAP Seksi Penyusunan Program sebagai berikut :

Kita upayakan kalo monev itu yang antusias waktu program berjalan kita kunjungi, untuk kerjasama berikutnya, terus belum pernah dimonev. Kita mau lihat pasca pelatihan itu gimana, kalo hari-hari kan monev itu tugas dari kabupaten. Sudah ada komitmen waktu temu karya. Kalau hari hari kita monev ya jelas ndak bisa. Mau minta masukan juga tentang program pelatihan kemarin apa masukannya dari peserta. Setelah diterapkan di daerah apa kesulitannya. (Wawancara 12 Mei 2014).
Kunjungan ke kabupaten asal peserta tersebut bertujuan untuk melihat secara langsung apakah peserta pelatihan telah berperan lebih baik usai pelatihan, apakah materi pelatihan dapat diterapkan oleh peserta. Wawancarapun dilakukan peserta pelatihan dan kepada atasan langsungnya misalkan dari pihak kabupaten mengenai unjuk kerja peserta pelatihan. Informasi dan sharing dari peserta pelatihan lebih diharapkan untuk menjadi masukan dan menggambarkan bagaimana materi pelatihan dapat diterapkan di daerah.

\section{Perbaikan Pelatihan}

Perbaikan pelatihan harus dilakukan dalam sebuah sistem pelatihan. Delapan tugas utama sistem pelatihan adalah sebagai berikut : 1) Membangun dukungan, 2)membangun kemampuan pelatihan kecakapan pelatihan secara keseluruhan, 3)pengembangan bahan pelatihan, 4)perencanaan strategis, 5)membangun jaringan sumber daya pelatihan, 6)pengembangan struktur intern, proses dan kebijakan, 7)tindakan improvisasi dan manajemen perbatasan, 8) penimbangan prestasi dan pengendalian [18].

Perbaikan pelatihan dengan membangun dukungan di Balai Besar Pemberdayaan Masyarakat dan Desa Kementerian Dalam Negeri di Malang dilaksanakan dengan adanya program peningkatan sumber daya manusia. Salah satu kegiatan dalam acara tersebut adalah membangun kebersamaan dan kerjasama lewat kegiatan outdoor, dengan adanya kegiatan tersebut dapat terjadi kekompakan dan kebersamaan dalam organisasi. Membangun dukungan juga dilaksanakan dengan cara formal dan informal. Cara formal komunikasi antara atasan dan bawahan adalah pelaksanaan apel pagi yang diikuti seluruh karyawan. Apel pagi bertujuan untuk membangun komitmen kerja serta pengecekan bahwa setiap karyawan telah siap menjalankan tugasnya. Cara komunikasi formal lainnya adalah pelaksanaan rapat koordinasi yang dilakukan pada saat diperlukan, biasanya pada awal atau akhir sebuah kegiatan. Komunikasi informal yaitu komunikasi antara atasan dan bawahan serta sesama karyawan untuk saling membangun komitmen lewat percakapan sehari-hari.

Perbaikan pelatihan di Balai Besar Pemberdayaan Masyarakat dan Desa Kementerian Dalam Negeri di Malang dalam hal membangun kemampuan pelatih dan kecakapan pelatih secara keseluruhan dilaksanakan bersamaan dengan pengembangan bahan 
pelatihan. Pengembangan bahan pelatihan dilaksanakan melalui program perbaikan modul. Pada saat perbaikan modul dilakukan bedah modul secara menyeluruh, dengan masukan narasumber dari instansi terkait atau perguruan tinggi untuk memberi masukan perihal materi pelatihan. sebagaimana disampaikan Bapak Naswir Darmansyah SH, MSi, Kepala Bidang Pemberdayaan Lembaga Kemasyarakatan sebagai berikut :

Kalau perbaikan program pelatihan yang bisa kita lakukan adalah perbaikan modul. Tentunya setiap modul adalah pijakan dari kegiatan yang kita lakukan. Dasar dari modul adalah regulasi. Kita perbaiki modul dan metode pelatihan. Kalau perbaikan kebijakan jelas bukan tupoksi kita, itu kaplingannya Dirjen PMD. Kita bisa kasi masukan berupa telaah staf, tapi jelas pembuat kebijakan bukan di balai ini. (Wawancara 2 Juni 2014).

Perencanaan strategis, pengembangan struktur intern, proses dan kebijakan, tindakan improvisasi dan manajemen perbatasan dilaksanakan dalam kaitannya dengan perbaikan pelatihan. Sehubungan hal tesebut dilakukan koordinasi dalam penyusunan rencana strategis tiap 4 tahun sekali serta adanya program sinkronisasi dan koordinasi antara istansi terkait di lingkungan Kementerian Dalam Negeri. Perlu dilakukan pengembangan dengan adanya bagian yang berkonsentrasi pada penelitian dan pengembangan, serta kerjasama dengan pihak pihak terkait untuk melakukan improvisasi dalam pelaksanaan program pelatihan serta dalam pengendaliannya. Pelaksanaan program tersebut rutin dilaksanakan, namun untuk mendapatkan sebuah perbaikan dan perubahan yang dapat terlihat nyata perlu pemikiran yang mendalam. Perencanaan strategis, pengembangan dan improvisasi dilaksanakan keseluruhan oleh seksi penyusunan program dengan 3 orang yang dirasa belum cukup untuk melakukan semua hal tersebut.

Membangun jaringan sumber daya pelatihan dilakukan oleh Balai Besar Pemberdayaan Masyarakat dan Desa Kementerian Dalam Negeri di Malang secara insidental karena tidak ada bagian atau seksi khusus yang membidangi bidang kerjasama dengan pihak luar. Kerjasama dengan pihak luar dilaksanakan bila dirasa dibutuhkan saja sesuai dengan tugas masingmasing seksi. Kerjasama yang selama ini dilaksanakan adalah dengan Kabupaten Kota tempat pelaksanaan studi lapang, perguruan tinggi dalam hal narasumber dan perbaikan modul, serta Balai Latihan Kerja atau sejenisnya untuk pelaksanaan praktek lapang pelatihan usaha ekonomi masyarakat. Kerjasama dalam hal pengiriman dilaksanakan apabila terdapat permintaan dari Kabupaten, Dirjen Pemberdayaan Masyarakat dan Desa maupun instansi lain yang membutuhkan.

Berdasarkan pembahasan terhadap hasil penelitian, dapat kita lihat bahwa titik lemah dari manajemen penyelenggaraan program pelatihan masyarakat tidak terletak pada sistem yang sudah ada, dikarenakan tahapan-tahapan telah memenuhi unsur manajemen. Titik lemah dikarenakan tidak adanya pemisahan tugas antara panitia dan pelatih masyarakat. Fungsi ganda tersebut mengakibatkan tidak maksimalnya fungsi dalam pelaksanaan tiap tahapan. Dikarenakan tidak adanya jabatan fungsional khusus pelatih masyarakat, maka panitia yaitu pejabat maupun staff melakukan kerja ganda. Kerja ganda tersebut tidak dapat dilaksanakan secara maksimal dan terdapat kecenderungan untuk melakukan fungsi panitia lebih utama dibandingkan fungsi menjadi pelatih masyarakat. Hal tersebut terbilang wajar karena memang fungsi utama pejabat dan staff adalah sebagai panitia.

Fungsi pelatih masyarakat banyak terlupakan utamanya dalam hal diskusi pelatih sebelum dan selama pelatihan berlangsung, perencanaan dan pengembangan metode pelatihan serta evaluasi pelatih. Diskusi pelatih tidak dilakukan secara terjadwal dan terstruktur, sehingga dilakukan sambil lalu dan terburu-buru. Perencanaan dan pengembangan metode pelatihan tidak dilakukan secara khusus, bahkan cenderung tidak ada inovasi dalam hal metode pembelajaran. Evaluasi pelatih tidak dilakukan sama sekali dan cenderung terlepas serta terlupakan dikarenakan tidak ada bagian khusus, serta tidak adanya sistem dan pelimpahan tugas untuk melaksanakan evaluasi pelatih. Untuk itulah disarankan untuk melakukan pemisahan tugas antara panitia dan pelatih masyarakat.Tugas panitia dalam setiap tahapan manajemen penyelenggaraan program pelatihan masyarakat berkonsentrasi pada urusan administrasi, surat menyurat, sarana prasarana serta kepentingan birokrasi dan komunikasi dengan pemerintah daerah, sedangkan tugas pelatih masyarakat berkonsentrasi pada urusan edukatif dan pengembangan metode serta materi pelatihan. 


\section{KESIMPULAN DAN SARAN}

\section{Kesimpulan}

1) Pelayanan publik pada penelitian ini adalah pelayanan di bidang kemasyarakatan yaitu bidang pendidikan orang dewasa, dilakukan menggunakan pola penyelenggaraan fungsional yang dilakukan oleh instansi tertentu.

2) Unsur unsur manajemen telah dilakukan dalam penyelenggaraan program pelatihan masyarakat telah dilaksanakan namun lebih mengarah pada unsur administratif dan belum dilakukan secara menyeluruh untuk unsur edukatif.

Kebaruan penelitian ini adalah temuan bahwa tindakan instansi penyelenggara untuk mengatasi ketiadaan jabatan fungsional pelatih masyarakat dengan melakukan kerja rangkap panitia sekaligus menjadi pelatih menyebabkan program dapat terselenggara secara baik dari sisi administratif saja, sedangkan dari sisi edukatif tidak dapat dicapai hasil maksimal. Kelebihan dari penelitian ini adalah dapat memotret penyelenggaraan program pelatihan secara menyeluruh dalam setiap tahapannya dari sudut penyelenggara layanan namun terdapat kekurangan dari penelitian ini yaitu tidak dilakukannya penelitian dari sudut penerima layanan.

Saran

1) Perlu adanya pembentukan jabatan fungsional teknis pelatih masyarakat yang bertugas khusus untuk menyampaikan materi pelatihan.

2) Bagi peneliti selanjutnya, agar melakukan penelitan dari sudut pandang penerima layanan yaitu peserta pelatihan.

\section{UCAPAN TERIMA KASIH}

Terimakasih kepada Pusdiklatren Bappenas dan Balai Besar Pemberdayaan Masyarakat dan Desa Kementerian Dalam Negeri di Malang.

\section{DAFTAR PUSTAKA}

[1] S. Notoadmojo, Pembangunan Sumber Daya Manusia, Jakarta: Rineka Cipta, 1997.

[2] S. Alwi, Manajemen Sumber Daya Manusia Strategi Keunggulan Kompetitif, Yogyakarta, 2012.

[3] M. Tjokrowinoto, Pembangunan: Dilema dan Tantangan, Yogyakarta: Pustaka Pelajar, 1996.

[4] S. Atmodirio, Manajemen Training, Jakarta: Balai Pustaka, 1993.
[5] H. A. S. Moenir, Manajemen Pelayanan Umum di Indonesia, Jakarta: Bumi Aksara, 1998.

[6] H. Pasolong, Teori Administrasi Publik, Bandung: Alfabeta, 2008.

[7] A. Dwiyanto, Manajemen Pelayanan Publik: Peduli, Inklusif dan Kolaboratif, Yogyakarta: Gajah Mada University Press, 2012.

[8] H. N. Tangkilisan, Manajemen Publik, Jakarta: PT Gramedia, 2005.

[9] W. H. Syafri, Studi Tentang IImu Administrasi Publik, Jakarta: Erlangga, 2012.

[10] Mahmudi, Manajemen Kinerja Sektor Publik, Yogyakarta: UPP STIM YKPN, 2007.

[11] M. S. Panggabean, Manajemen Sumber Daya Manusia, Bogor: Ghalia Indonesia, 2004.

[12] A. T. Sulistyani dan Rosidah, Manajemen Sumber Daya Manusia, Konsep, Teori dan Pengembangan Dalam Konteks Organisasi Publik, Yogyakarta: Graha Ilmu, 2009.

[13] A. A. Mangkunegara, Perencanaan dan Pengembangan Sumber Daya Manusia, Bandung: Refika Aditama, 2006.

[14] I. K. Syafie, Ilmu Administrasi Publik, Jakarta: Rineka Cipta, 1999.

[15] A. Nasar dan U. Muhammad, "Training Stategically Improves Human Resource (HR) Productivity in Academic Institutions of Pakistan," MPRA Paper, vol. 54141, 2014.

[16] Sedarmayanti, Manajemen Sumber Daya Manusia, Reformasi Birokarasi dan Manajemen Pegawai Negeri Sipil, Bandung: Refika Aditama, 2009.

[17] H. Suprijanto, Pendidikan Orang Dewasa Dari Teori Hingga Aplikasi, Jakarta: Bumi Aksara, 2011.

[18] H. Simamora, Manajemen Sumber Daya Manusia, III penyunt., Yogyakarta: Bagian Penerbitan STIE YKPN, 2006.

[19] R. Lynton dan U. Pareek, Pelatihan dan Pengembangan Tenaga Kerja, Jakarta: PT Pustaka Binaman, 1998. 